\title{
The influence of environmental tax rates on the Levelized cost of heat on the example of organic and biofuels boilers in Ukraine
}

\author{
Valentyna Stanytsina ${ }^{1, *}$, Volodymyr Artemchuk ${ }^{2,3}$, Olga Bogoslavska $^{1}$, Iryna Zinovieva ${ }^{4}$, and Nataliia Ridei $^{5}$ \\ ${ }^{1}$ Institute of general energy of NAS of Ukraine, 172 Antonovych Str., Kyiv, 03150, Ukraine \\ ${ }^{2}$ G.E. Pukhov Institute for Modelling in Energy Engineering of NAS of Ukraine, 15 General Naumov Str., Kyiv, 03164, Ukraine \\ ${ }^{3}$ State Institution "The Institute of Environmental Geochemistry of National Academy of Sciences of Ukraine”, 34a Palladin Ave., \\ Kyiv, 03142 \\ ${ }^{4}$ Kyiv National Economic University named after Vadym Hetman, 54/1 Prospect Peremogy, Kyiv, 03057, Ukraine \\ ${ }^{5}$ National Dragomanov Pedagogical University, 9 Pyrohova Str., Kyiv, 01601, Ukraine
}

\begin{abstract}
In December 2019, the European Commission officially presented The European Green Deal, a new EU economic development program aimed at achieving climate neutrality on the European continent by 2050. Many previous global, European, and national programs also aim to reduce emissions of pollutants into the atmosphere. In this context, one of the ways to reduce emissions is the development of alternative energy sources (in particular the wider use of biofuel boilers) and increasing environmental tax rates. When choosing the optimal heating boilers, the practice of using the levelized cost of heating ( $\mathrm{LCOH}$ ) indicator is common. Environmental pollution tax (as a component of $\mathrm{LCOH}$ ) is calculated for the three most common types of boilers (for Ukrainian boiler houses) with a capacity of 4.65 to $58 \mathrm{MW}$, burning natural gas, coal, and fuel oil, as well as low-power boilers burning organic and biofuels, for existing environmental tax rates, for projected increasing in 4 times (according to the bill) and subject to the introduction of minimum and maximum rates in EU countries. It is established that at the current environmental tax rates in Ukraine there are almost no economic incentives for the introduction of technologies to reduce the concentration of pollutants in emissions, but increasing environmental tax rates may change this situation. This, in turn, once again suggests that changing environmental tax rates can be an effective tool for achieving sustainable development goals.
\end{abstract}

\section{Introduction}

At the present stage of development, humanity uses so many resources that for the future in the near future we will lack the resources of our planet. Therefore, the global concept for solving this problem has become "sustainable development" - a development that meets the needs of the modern generation without harming future generations.

In a situation of stability, two competing pillars of sustainable development: the economic and the environmental one, are in the lead - as long as the basic needs of most people are satisfied [1].

Ukraine has made a number of commitments to protect the environment and reduce pollutant emissions [2, 3, 4]. The EU has adopted Directive 2015/2193 of the European Parliament and of the Council of 25 November 2015 on the limitation of emissions of certain pollutants into the air from medium combustion plants [5]. As this Directive is a supplement to Directive 2010/75 / EC (for installations over $50 \mathrm{MW}$ ), Ukrainian medium-capacity installations will have to prepare to comply with its standards.

Among budgetary and fiscal instruments for stimulating and ensuring sustainable development, environmental taxes occupy a prominent place.
In scientific publications and legislation of different countries, you can find different definitions of "environmental taxes". In particular, the legislation of Ukraine contains two such definitions that to some extent complement each other:

1) Environmental tax - a nationwide mandatory payment, which is based on the actual amount of emissions into the atmosphere, discharges of pollutants into water bodies, waste disposal, the actual amount of radioactive waste temporarily stored by their producers, the actual amount of generated radioactive waste and the actual the amount of radioactive waste accumulated before April 1, 2009 [6].

2) Environmental tax - a tax with a specific object of taxation, which clearly has a negative impact on the environment, or is aimed at taxing certain activities, goods or services so that the cost of environmental protection can be included in their price and/or guide producers and consumers for activities that are best for the environment [7].

Many countries around the world have long used this powerful toolkit, many are just beginning, but common to most countries is that legislation in this area is constantly improving, including changes in environmental tax rates.

\footnotetext{
Corresponding author: st_v_v@hotmail.com
} 
Ukraine is no exception. As of December 2020, there are 3 different bills in the Parliament of Ukraine, about increasing the rates of environmental tax in Ukraine.

Given that one of the industries that are significantly affected by environmental tax rates is heat, it is advisable to conduct a study on the effects of changes in environmental tax rates on economic and environmental pillars of sustainable development.

\section{Literature review}

This article is a continuation of previous research by the authors $[8,9]$. A lot of work has been devoted to the study of the impact of environmental taxes on sustainable development goals. Consider the main ones for 20182020

The study [10] employs the GTAP-E-Power model with additional improvements to include non-CO 2 emissions to examine the impacts of such a policy on the Vietnamese economy. Authors show, that higher tax on coal would foster the extension of renewable energy sectors faster than the impacts resulted from increasing tax on petroleum products. The increased demands by the private sector for electricity generated from renewable sources signal the potential for sustainable development of the renewable electricity generation sectors in Vietnam.

In paper [11] authors consider from an environmental policy-maker perspective, how carbon reduction policies impact the economic competitiveness of the manufacturing sector and note that the obtained results offer support to both environmental policy-makers and corporate production and sustainability managers to determine whether it is technically feasible and profitable to replace traditional scheduling strategies with environmentally friendly scheduling strategies.

Article [12] study how new sustainable business models in the energy sector work, and investigate their risk profile, especially concerning the risk of regulatory changes.

Paper [13] investigates the determinants of environmental tax revenue.

Findings [14] clearly indicate that (a) the proportion of tourism energy consumption to national energy consumption in China will increase over time, (b) the impacts of a carbon tax on China's tourism fossil energy consumption, electricity consumption, and energy intensity will become increasingly weak, (c) the impacts of a carbon tax on electricity use are greater than the impacts on fossil fuel consumption, and (d) the impacts of different carbon taxes on the levels of energy consumption and energy intensity will vary to a significant degree between the different tourism sectors.

The study [15] introduced an original interdisciplinary assessment model of performance-based contracting for $\mathrm{SO}_{2}$ emission control in Chinese coal power plants that involves key environmental policies including commandand-control regulations, market-based approaches, and administrative measures, as well as technology, market, and capital variables (Fig. 1).

Paper [16] describes a new carbon price mechanism with full emission coverage which developed within the framework of a global computable general equilibrium model (GTAP-E-PowerS) to enhance the capacity and accuracy for climate change and energy policy assessment. The results indicate that South Africa is likely to move to low carbon and sustainable economy with such a policy.

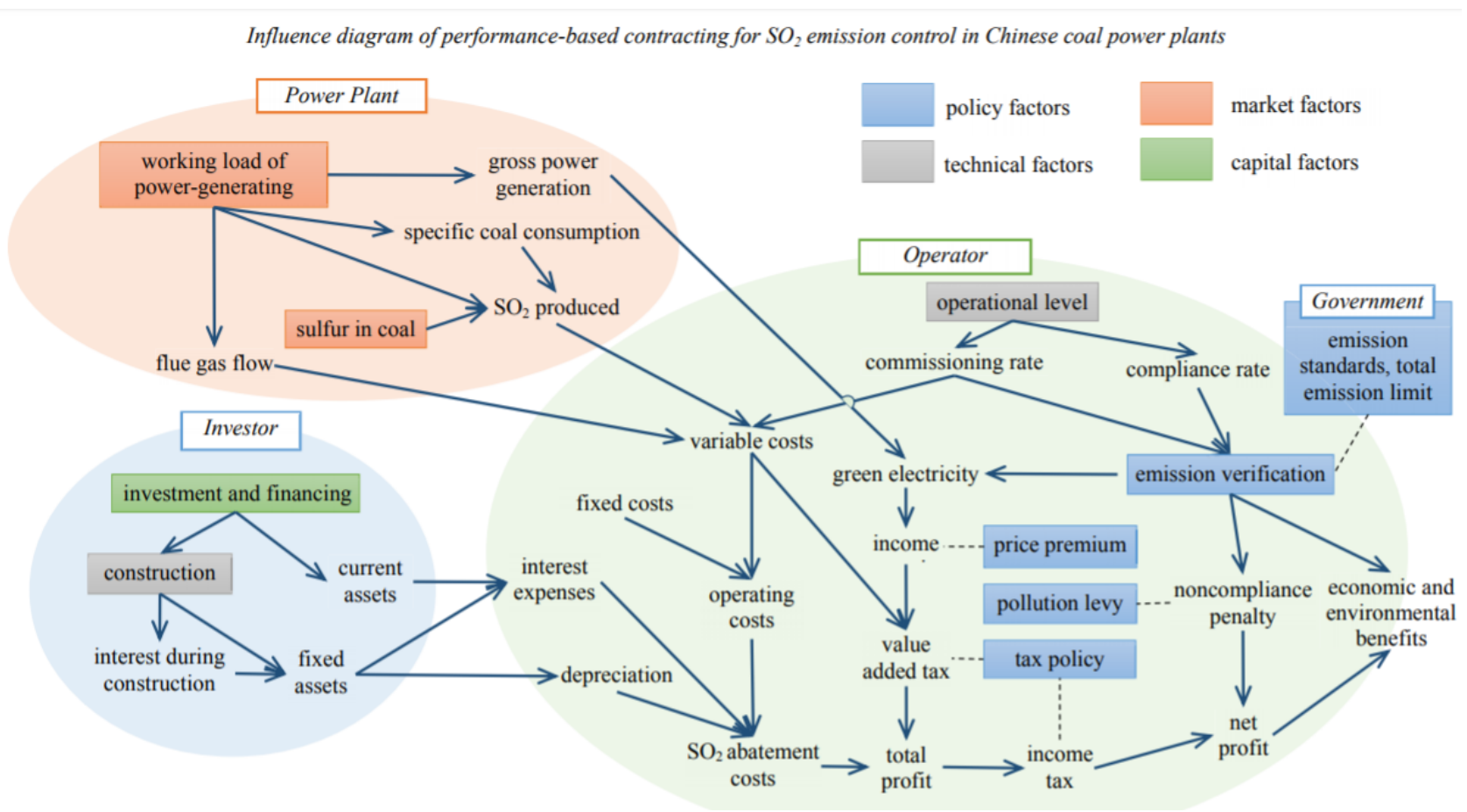

Fig. 1. Stakeholders, uncertain factors, and interactions in performance-based contracting for SO2 emission control in Chinese coal power plants. Arrows indicate the dependence; dashed lines indicate the environmental policy boundaries [15]. 
Article [17] shows, that the required carbon tax begins from $\$ 5.29 /$ ton in 2020 and grows on average by $3.5 \%$ reaching up to $\$ 35.83$ per ton carbon towards the year 2075.

In paper [18] is writing, that towards the reduction of greenhouse gas emissions, a carbon tax has been already introduced in 40 countries, but owing to different carbon prices among countries, there are potential risks of carbon leakage, where manufacturers transfer production operations to countries with lower taxes to pursue lower costs.

The paper [19] deals with the greening of tax systems in the European Union (EU) and reviews the achievements of the Baltic States in relation to greening their tax systems and implementing the sustainable energy development goals set by the EU's energy policies.

The Levelized cost of energy (LCOE) and its analog for heating - Levelized cost of heating $(\mathrm{LCOH})$ are the widespread indicators, which is often used for cost comparisons for energy and heating generation [20-23 and other].

Paper [20] shows, that the application of the "traditional" LCOE formula has some problems, therefore authors present a modification to the traditional LCOE formula, which considers energy price rise and thus allows more accurate LCOE calculations.

The study [22] presents a new approach and methodology, which developed which uses the United Kingdom "audited" data, published in company accounts, that has been obtained from Companies House, to determine more accurate LCOE estimates.

The paper [23] provides the techno-economic comparative analysis of eight Biomass Integrated Gasification Combined Cycle (BIGCC) system designs that include the technology options of the biomass gasification, the power generation, and the $\mathrm{CO}_{2}$ emission control. Results show that the LCOE of these systems is ranged from $0.131 \$ / \mathrm{kWh}$ to $0.259 \$ / \mathrm{kWh}$.

\section{Methods}

The initial data for calculating emission taxes are the annual consumption of a particular type of fuel by the boiler plant (determined by the thermal capacity and efficiency of the boiler plant, its operating time, and installed capacity utilization factor), fuel calorific value, pollutant emission factors and eco tax rates.

Table 1 shows the emission factors of pollutants during the combustion of different fuels without the use of technologies to reduce emissions of pollutants.

Table 2 shows the tax rates for air emissions of certain pollutants by stationary sources of pollution, which include boilers of heating boilers, according to Articles 243.1 and 243.4 of the Tax Code of Ukraine [6].

In November 2019, 3 bills (draft laws) on increasing environmental tax rates were submitted to the Verkhovna Rada. The bill on Amendments to the Tax Code of Ukraine to increase environmental tax rates and implement European principles of modernization of Ukrainian industry 2367-1 of November 18, 2019, proposes to increase tax rates for air emissions from 2030. According to this bill the growth rate will be gradual: from 01 January 2021 to December 31, 2022, inclusive, tax rates are $75 \%$ of the rates provided by the bill, in 2023$2024-80 \%$, in 2025-2026 - 85\%, in 2027-2029 - 90\%.

Bill 2367 of November 1, 2019 proposes to increase tax rates by 4 times (Table 2 ).

In EU countries, tax rates differ dozens of times, in Poland some of the lowest in the EU, in Sweden - the highest (Table 3), the rate - 34.64 UAH/EUR.

Sweden levies the highest carbon tax rate at $€ 112.08$ (US\$ 132.17) per ton of carbon emissions, followed by Switzerland (€83.17, \$98.08) and Finland (€62.00, $\$ 73.11)$. You'll find the lowest carbon tax rates in Poland $(€ 0.07, \$ 0.08)$, Ukraine (€0.33, \$0.39), and Estonia $(€ 2.00, \$ 2.36)$.

Table 1. Specific pollutant emissions from fuel combustion

\begin{tabular}{|c|c|c|c|c|c|c|c|c|}
\hline \multirow{2}{*}{ Fuel } & \multicolumn{4}{|c|}{$\begin{array}{c}\text { Specific pollutant emissions, } \\
\mathrm{kg} / \mathrm{t} \text { fuel }\end{array}$} & \multicolumn{4}{|c|}{ Fuel pollutant emission index, g/GJ } \\
\hline & NO $_{\mathbf{x}}$ & SO $_{x}$ & $\mathrm{CO}_{2}$ & $\mathbf{P M}_{10}$ & NO $_{\mathbf{x}}$ & SO $_{\mathbf{x}}$ & $\mathrm{CO}_{2}$ & $\mathbf{P M}_{10}$ \\
\hline natural gas & $\begin{array}{c}2.127 \\
{[*]}\end{array}$ & $\begin{array}{c}0 \\
0 \\
{[*]}\end{array}$ & $\begin{array}{c}1943.4 \\
{[*]}\end{array}$ & $\begin{array}{c}0.00 \\
{[*]}\end{array}$ & $\begin{array}{c}64.31 \\
{[28]}\end{array}$ & $\begin{array}{c}0 \\
{[28]}\end{array}$ & $\begin{array}{c}58748 \\
{[28]}\end{array}$ & $\begin{array}{c}0 \\
{[*]}\end{array}$ \\
\hline coal & $\begin{array}{c}2.065 \\
{[*]}\end{array}$ & $\begin{array}{c}51.30 \\
{[*]}\end{array}$ & $\begin{array}{c}1918.9 \\
{[*]}\end{array}$ & $\begin{array}{c}47.20 \\
{[*]}\end{array}$ & $\begin{array}{c}100.9 \\
{[28]}\end{array}$ & $\begin{array}{l}2506 \\
{[28]}\end{array}$ & $\begin{array}{c}93740 \\
{[28]}\end{array}$ & $\begin{array}{c}2305.9 \\
{[*]}\end{array}$ \\
\hline fuel oil & $\begin{array}{c}2.494 \\
{[*]}\end{array}$ & $\begin{array}{c}19.40 \\
{[*]}\end{array}$ & $\begin{array}{c}2973.0 \\
{[*]}\end{array}$ & $\begin{array}{c}15.74 \\
{[*]}\end{array}$ & $\begin{array}{c}64.311 \\
{[28]}\end{array}$ & $\begin{array}{c}500.26 \\
{[28]}\end{array}$ & $\begin{array}{c}76662,63 \\
{[28]}\end{array}$ & $\begin{array}{c}405,81 \\
{[28]}\end{array}$ \\
\hline wood chips & $\begin{array}{c}0.928 \\
{[*]}\end{array}$ & $\begin{array}{c}0.112 \\
{[*]}\end{array}$ & $\begin{array}{c}1020 \\
{[*]}\end{array}$ & $\begin{array}{c}0.903 \\
{[*]}\end{array}$ & $\begin{array}{c}91 \\
{[25]}\end{array}$ & $\begin{array}{c}11 \\
{[25]}\end{array}$ & $\begin{array}{c}100000 \\
{[26]}\end{array}$ & $\begin{array}{l}88.5 \\
{[25]}\end{array}$ \\
\hline wood pellet & $\begin{array}{c}1.36 \\
{[*]}\end{array}$ & $\begin{array}{c}0.187 \\
{[*]}\end{array}$ & $\begin{array}{c}1700 \\
{[*]}\end{array}$ & $\begin{array}{c}1 \\
0.51 \\
{[*]}\end{array}$ & $\begin{array}{c}80 \\
{[25]}\end{array}$ & $\begin{array}{l}11 \\
{[25]}\end{array}$ & $\begin{array}{c}100000 \\
{[26]}\end{array}$ & $\begin{array}{c}30 \\
30 \\
{[25]}\end{array}$ \\
\hline sunflower husk pellets & $\begin{array}{l}1.36 \\
{[27]}\end{array}$ & $\begin{array}{c}3.2 \\
{[27]}\end{array}$ & $\begin{array}{c}1816.1 \\
{[27]}\end{array}$ & $\begin{array}{c}0.091 \\
{[*]}\end{array}$ & $\begin{array}{c}75.56 \\
{[*]}\end{array}$ & $\begin{array}{c}207.4 \\
{[27]}\end{array}$ & $\begin{array}{c}100893 \\
{[27]}\end{array}$ & $\begin{array}{c}5.911 \\
{[*]}\end{array}$ \\
\hline straw briquettes & $\begin{array}{l}1.38 \\
{[27]}\end{array}$ & $\begin{array}{c}2 \\
{[27]}\end{array}$ & $\begin{array}{c}1544.2 \\
{[27]}\end{array}$ & $\begin{array}{c}0.171 \\
{[*]}\end{array}$ & $\begin{array}{c}89.03 \\
{[*]}\end{array}$ & $\begin{array}{l}127.4 \\
{[27]}\end{array}$ & $\begin{array}{c}99624 \\
{[27]}\end{array}$ & $\begin{array}{c}10.892 \\
{[*]}\end{array}$ \\
\hline firewood & $\begin{array}{c}1.228 \\
{[*]}\end{array}$ & $\begin{array}{c}0.149 \\
{[*]} \\
\end{array}$ & $\begin{array}{c}1512 \\
{[*]}\end{array}$ & $\begin{array}{c}1.195 \\
{[*]}\end{array}$ & $\begin{array}{c}91 \\
{[25]}\end{array}$ & $\begin{array}{c}11 \\
{[25]}\end{array}$ & $\begin{array}{c}112000 \\
{[*]}\end{array}$ & $\begin{array}{l}88.5 \\
{[25]}\end{array}$ \\
\hline peat briquettes & $\begin{array}{c}2.76 \\
{[*]}\end{array}$ & $\begin{array}{c}2 \\
{[*]}\end{array}$ & $\begin{array}{c}1860.3 \\
{[*]}\end{array}$ & $\begin{array}{c}1 \\
0.51 \\
{[*]}\end{array}$ & $\begin{array}{c}178.1 \\
{[*]}\end{array}$ & $\begin{array}{c}127.4 \\
{[*]}\end{array}$ & $\begin{array}{c}106000 \\
{[*]}\end{array}$ & $\begin{array}{c}30 \\
{[*]}\end{array}$ \\
\hline
\end{tabular}

* calculated by the authors on the basis of data $[24,25,26,27,28,29]$ 
Table 2. Actual and project tax rates for air emissions of some pollutants, UAH/t

\begin{tabular}{|c|c|c|c|c|c|c|c|}
\hline \multirow{2}{*}{ Pollutant } & \multirow{2}{*}{ Existing tax rates } & \multicolumn{4}{|c|}{ Bill 2367-1 of November 18, 2019 } & \multirow{2}{*}{ Bill 2367 of November 1, 2019 } \\
\cline { 2 - 7 } & & $\mathbf{2 0 2 1 - 2 0 2 2}$ & $\mathbf{2 0 2 3 - 2 0 2 4}$ & $\mathbf{2 0 2 5 - 2 0 2 6}$ & $\mathbf{2 0 2 7 - 2 0 2 9}$ & $\mathbf{2 0 3 0}$ & \\
\hline $\mathrm{NO}_{2}$ & 2451.84 & 2758.32 & 2942.21 & 3126.10 & 3309.98 & 3677.76 & 9807.36 \\
\hline $\mathrm{N}_{2} \mathrm{O}$ & 2451.84 & 2758.32 & 2942.21 & 3126.10 & 3309.98 & 3677.76 & 9807.36 \\
\hline $\mathrm{CH}_{4}$ & 138.57 & 155.895 & 166.29 & 176.681 & 187.07 & 207.86 & 554.28 \\
\hline $\mathrm{PM}_{10}$ & 92.37 & 103.92 & 110.85 & 117.776 & 124.70 & 138.56 & 369.48 \\
\hline $\mathrm{SO}_{2}$ & 2451.84 & 2758.32 & 2942.21 & 3126.10 & 3309.98 & 3677.76 & 9807.36 \\
\hline
\end{tabular}

Table 3. Tax rates for air emissions of certain pollutants in Ukraine, Poland and Sweden

\begin{tabular}{|c|c|c|c|c|c|}
\hline \multirow{2}{*}{ Pollutant } & Ukraine & Poland & Sweden & Poland & Sweden \\
\cline { 2 - 6 } & \multicolumn{3}{|c|}{ UAH/t } & \multicolumn{2}{c|}{ EUR/t } \\
\hline $\mathrm{NO}_{\mathrm{x}}$ & 2451.84 & 4387.8 & 18359.2 & 126.67 & 530 \\
\hline $\mathrm{CO}_{2}$ & 10.00 & 2.4 & 3882.5 & 0.07 & 112.08 \\
\hline $\mathrm{SO}_{2}$ & 2451.84 & 4387.8 & 10392 & 126.67 & 300 \\
\hline
\end{tabular}

\section{Carbon Taxes in Europe}

Carbon Tax Rates per Ton of CO2e, as of 2019

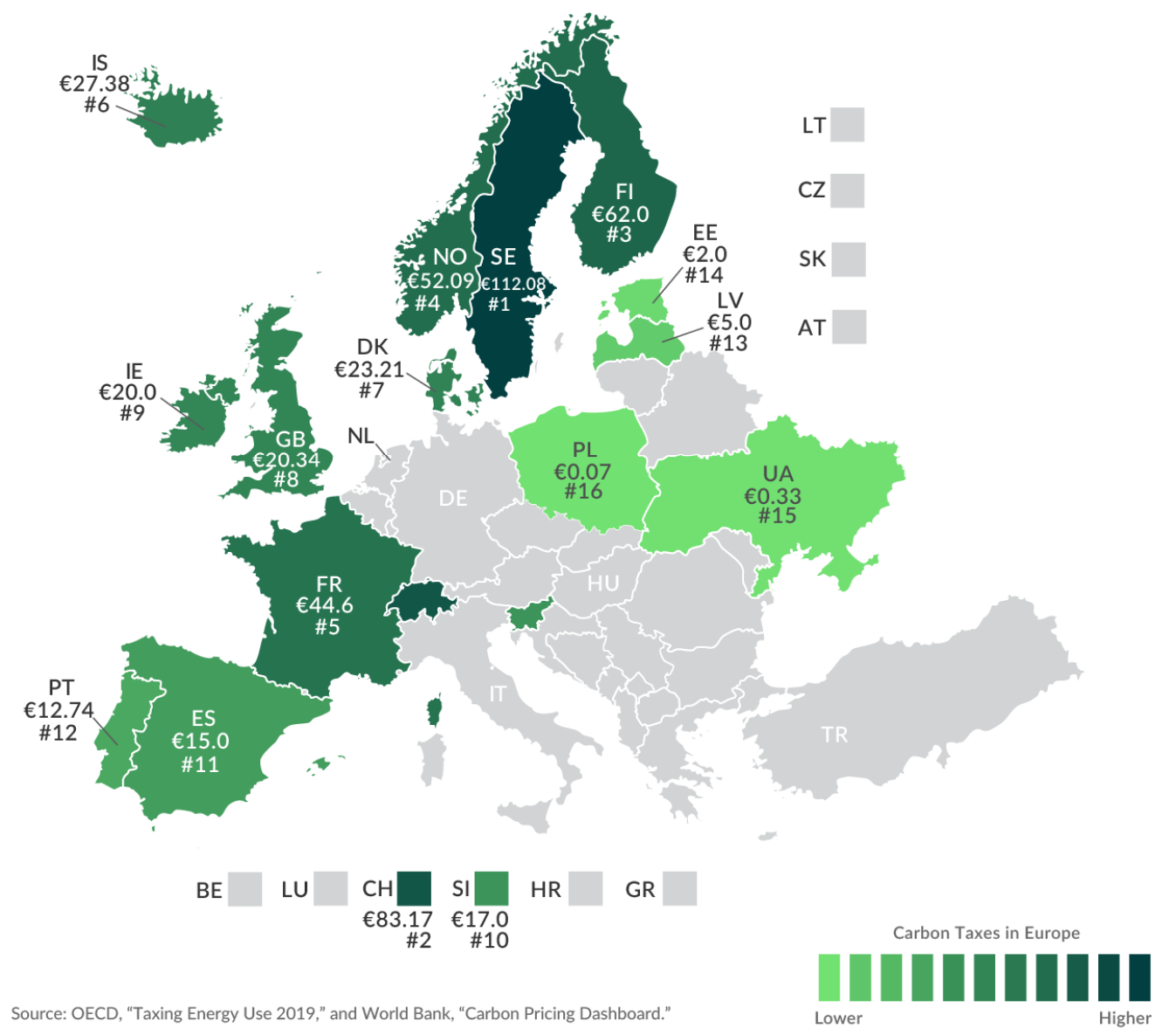

Fig. 2. Carbon Taxes in Europe [30].

It is proposed to calculate the levelized cost of heat taking into account the environmental tax, by the expression:

where:

$$
\mathrm{LCOH}_{T_{e c o}}=\frac{\sum_{t=1}^{N} \frac{I_{t}+M_{t}+F_{t}+T_{t}^{e c o}}{(1+r)^{t}}}{\sum_{t=1}^{N} \frac{H_{t}}{(1+r)^{t}}}
$$

$I_{t}$ is investment expenditures in year $t$

$M_{t}$ is operations and maintenance expenditures in year $t$

$F_{t}$ is fuel expenditures in year $t$
$H_{t}$ is energy (heat) generation in year $t$

$r$ is discount rate

$N$ is lifetime of the technology $T_{t}^{e c o}$ is environmental tax.

Thus, the change in $\mathrm{LCOH}$ due to the environmental tax is determined by the expression:

$$
\triangle \mathrm{LCOH}_{\text {eco } \text { tax }}=\mathrm{LCOH}_{T_{\text {eco }}}-\mathrm{LCOH}
$$


Taxation of pollutant emissions in Ukraine is carried out in accordance with Section VIII of the Tax Code of Ukraine [6].

The expenditures included in the formula for determining the levelized cost of heat are divided into permanent (administrative) and variable (operational) costs.

\section{Results and discussion}

For the study, the authors used data from [9, 31], which was calculated the $\mathrm{LCOH}$ and the contribution of environmental tax in LCOH for three types of boilers with a capacity of 4.65 to $58 \mathrm{MW}$, burning natural gas, coal and fuel oil, which the most common for boiler houses of Ukraine [9], and for boilers on different types of biofuels with a capacity of $1 \mathrm{MW}$ [31].

$\triangle \mathrm{LCOH}_{\text {eco tax }}$ is calculated to an increase in eco tax rates by $50 \%$ and 4 times (according to Ukrainian bills) and the eco tax rates in Poland (one of the lowest in the EU) and Sweden (highest in the EU).

The contribution of the environmental tax to the $\mathrm{LCOH}$ indicator depending on the different rates of the environmental tax, which were given in tables 2 and 3 , are presented in the table. 4

Table 4. $\triangle \mathbf{L C O H}_{\text {eco tax }}$ at eco tax rates of Ukraine (current and project), Poland and Sweden for boilers on different fuels

\begin{tabular}{|c|c|c|c|c|c|c|c|c|}
\hline \multirow{3}{*}{ Boiler, its power } & \multirow{3}{*}{ Fuel type } & \multirow{3}{*}{$\begin{array}{c}\text { LCOH } \\
\text { without } \\
\text { eco tax }\end{array}$} & \multicolumn{6}{|c|}{$\Delta L C O H_{e c o t a x}$} \\
\hline & & & \multirow[t]{2}{*}{ Ukraine } & \multicolumn{2}{|c|}{$\begin{array}{c}\text { Ukraine, Bill 2367-1 of } \\
\text { November } 18,2019\end{array}$} & \multirow{2}{*}{$\begin{array}{l}\text { Ukraine, Bill } 2367 \text { of } \\
\text { November } 1,2019\end{array}$} & \multirow[t]{2}{*}{ Poland } & \multirow[t]{2}{*}{ Sweden } \\
\hline & & & & from 2021 & from 2030 & & & \\
\hline \multirow{2}{*}{$\begin{array}{l}\text { KV-GM-4-150, } \\
4.65 \mathrm{MW}\end{array}$} & natural gas & 1047.34 & 3.33 & 3.42 & 3.68 & 13.34 & 1.84 & \begin{tabular}{|l|}
994.61 \\
\end{tabular} \\
\hline & fuel oil & 1278.33 & 9.93 & 10.72 & 13.11 & 39.72 & 17.18 & 1359.99 \\
\hline \begin{tabular}{|l|} 
KV-TS-4, 4.65 \\
MW \\
\end{tabular} & thermal coal & 705.27 & 36.75 & 40.68 & 52.48 & 146.98 & 87.38 & 1865.55 \\
\hline \multirow{2}{*}{$\begin{array}{l}\text { KV-GM -50-150, } \\
58.2 \mathrm{MW}\end{array}$} & natural gas & 1027.65 & 3.38 & 3.47 & 3.73 & 13.54 & 1.87 & 1009.66 \\
\hline & fuel oil & 1241.06 & 9.85 & 10.64 & 13.01 & 39.41 & 17.05 & 1349.54 \\
\hline \begin{tabular}{|l|} 
KV-TS -20, 23.2 \\
MW \\
\end{tabular} & thermal coal & 708.42 & 37.31 & 41.30 & 53.28 & 149.24 & 88.72 & 1894.23 \\
\hline KV-2.0, 2 MW & natural gas & 1090.08 & 3.40 & 3.49 & 3.75 & 13.61 & 1.88 & 1015.15 \\
\hline \multirow{4}{*}{$\begin{array}{l}\text { ARS 1000, } 1 \\
\text { MW }\end{array}$} & anthracite & 720.45 & 38.61 & 42.80 & 55.40 & 154.42 & 93.49 & 2090.03 \\
\hline & wood & 529.64 & 7.30 & 7.48 & 7.99 & 29.22 & 5.17 & 2313.97 \\
\hline & wood chips & 687.35 & 6.59 & 6.75 & 7.26 & 26.34 & 4.95 & 2041.22 \\
\hline & natural gas & 1125.28 & 3.79 & 3.90 & 4.20 & 15.18 & 2.16 & 1167.51 \\
\hline \multirow{2}{*}{\begin{tabular}{|l} 
ARS $1000 \mathrm{BM}$, \\
$0.98 \mathrm{MW}$ \\
\end{tabular}} & wood pellets & 634.14 & 5.58 & 5.71 & 6.09 & 22.32 & 3.32 & 1774.06 \\
\hline & wood & 492.70 & 6.71 & 6.87 & 7.34 & 26.84 & 4.75 & 2125.62 \\
\hline \multirow{3}{*}{$\begin{array}{l}\text { Gefest Profi-P } \\
\text { 1000, 1 MW }\end{array}$} & straw briquettes & 521.04 & 7.03 & 7.34 & 8.25 & 28.12 & 5.63 & 1793.16 \\
\hline & wood pellets & 637.96 & 5.58 & 5.71 & 6.09 & 22.32 & 3.32 & 1774.06 \\
\hline & \begin{tabular}{|c|}
$\begin{array}{c}\text { sunflower husk } \\
\text { pellets }\end{array}$ \\
\end{tabular} & 379.18 & 7.75 & 8.15 & 9.33 & 31.00 & 6.84 & 1798.75 \\
\hline
\end{tabular}

In case of eco tax rates increasing for emissions of all pollutants in 4 times, the mentioned component of the $\mathrm{LCOH}$ will increase for natural gas boilers - from 3.40 to 13.34 UAH/Gcal, for fuel oil boilers will increase from 10 to $40 \mathrm{UAH} / \mathrm{Gcal}$, for coal-fired boilers - from almost 40 to $150 \mathrm{UAH} / \mathrm{Gcal}$.

For biofuel boilers the growth will be from 6-7 to 22$28 \mathrm{UAH} / \mathrm{Gcal}$, namely from 5.58 to $22.32 \mathrm{UAH} / \mathrm{Gcal}$ for wood pellets boilers, from 7.75 to $31.00 \mathrm{UAH} / \mathrm{Gcal}$ for sunflower husk pellets boilers.

At current eco tax rates $\Delta \mathbf{L C O H}$ eco tax is from $0.3 \%$ for gas boilers to $5.3 \% \mathrm{LCOH}$, for biofuel boilers from $0.9 \%$ (wood pellets) to $2.0 \%$ (sunflower husk pellets). If the eco tax rates are increased in 4 times, it will be from $1.2 \%$ (gas boilers) to $21 \% \mathrm{LCOH}$ (coal boilers).

Poland has the lowest environmental tax rates in EU, so the environmental component of $\mathrm{LCOH}$ (taxes), for their case will increase for fuel oil boilers by $70 \%$; for coal-fired boilers it will more than double, and for natural gas boilers it will generally halve (due to a lower $\mathrm{CO}_{2}$ tax rate).

If the highest rates in the EU (Sweden) are used, the environmental component $\mathrm{LCOH}$ (tax) for coal-fired boilers will be in 2.6 times larger as the investment, operating and fuel costs component, for gas boilers, the environmental component will be $95 \%$, and for fuel oil boilers - $105 \%$, for biofuel boilers - will be in 2.8-4.7 times larger. The largest contribution is the tax on $\mathrm{CO}_{2}$ emissions, the tax rate of which is 388 times higher than in Ukraine. The environmental component LCOH (tax) under these conditions is tens of thousands of times higher than at existing tax rates in Ukraine.

With the introduction of Sweden tax rates, the cheapest will be heat from high-power gas boilers - 2040 $\mathrm{UAH} / \mathrm{Gcal}$, heat from boilers burning some types of biofuels $(2728,2843 \mathrm{UAH} / \mathrm{Gcal})$ becomes more expensive even than heat from fuel oil and coal boilers (2570-2638 UAH/Gcal). This will stimulate further introduction and use of gas boilers, which contradicts the goal of increasing the share of local biofuels.

In many countries around the world, including $\mathrm{EU}$ countries, biofuels are considered $\mathrm{CO}_{2}$ neutral and no $\mathrm{CO}_{2}$ tax is levied. Subject to the introduction of Swedish taxfree rates for $\mathrm{CO}_{2}$ emissions, the environmental component of $\mathrm{LCOH}$ (taxes) for biofuel boilers will range from 7.2 to $16.1 \mathrm{UAH} / \mathrm{Gcal}$. 


\section{Conclusions}

In December 2019, the European Commission officially presented The European Green Deal, a new EU economic development program aimed at achieving climate neutrality on the European continent by 2050. Many previous global, European, and national programs also aim to reduce emissions of pollutants into the atmosphere. In this context, one of the directions is the development of alternative energy sources (in particular the wider use of biofuel boilers) on the one hand and increasing environmental tax rates on the other (which will lead to reduced emissions).

Many leading countries in the world have long used changes in environmental tax rates as one of the tools to achieve sustainable development goals. Ukraine is also trying to join them. As of December 2020, there are 3 different bills in the Parliament of Ukraine, the adoption of which will change the rates of environmental tax in Ukraine, sometimes in times. However, as of December 30,2020 , none of these bills have been adopted.

It is established that at the current environmental tax rates in Ukraine there are almost no economic incentives for the introduction of technologies to reduce the concentration of pollutants in emissions, but increasing environmental tax rates may change this situation, and environmental tax rates will be an effective tool for achieving sustainable development goals in Ukraine.

The authors calculated the environmental component of LCOH (taxes) at eco-tax rates of Ukraine (current and project), Poland, and Sweden for boilers on different fuels. If the highest rates in the EU (Sweden) are used, the environmental component $\mathrm{LCOH}$ (tax) for all fuel type boilers will be equal to the investment, operating and fuel costs component for natural gas and fuel oil boilers, in 2.6-4.7 times larger for coal and biofuel boilers. The cheapest will be heat from high-power gas boilers - 2040 $\mathrm{UAH} / \mathrm{Gcal}$, heat from boilers burning some types of biofuels (2728, $2843 \mathrm{UAH} / \mathrm{Gcal})$ becomes more expensive even than heat from fuel oil and coal boilers (2570-2638 UAH/Gcal). This will stimulate further introduction and use of gas boilers, which contradicts the goal of increasing the share of local biofuels.

Only increasing the rates of the eco-tax without its smart administration (for example, benefits, refund of part of the funds for the eco-modernization, etc.) will not ensure the effective use of these tools to achieve sustainable development goals.

\section{References}

1. P. Rydzewski, Between economy and security. dilemmas of sustainable development in the COVID19 era - an example of great britain, Problemy Ekorozwoju, 15(2), 15-21 (2020).

2. Law of Ukraine "On Ratification of the Association Agreement between Ukraine, of the one part, and the European Union, the European Atomic Energy Community and their Member States, of the other part” of 16 September 2014 № 1678-VII, https://zakon.rada.gov.ua/laws/show/1678-18\#Text,
Accessed 30 Dec 2020

3. Law of Ukraine "On Ratification of the Protocol on the Accession of Ukraine to the Treaty establishing the Energy Community” of 15.12.2010 № 2787-VI, https://zakon.rada.gov.ua/laws/show/2787-17\#Text, Accessed 30 Dec 2020

4. National plan to reduce emissions from large combustion plants. Order of the Cabinet of Ministers of Ukraine of November 8, 2017 № 796-r, https://zakon.rada.gov.ua/laws/show/796-2017\%D1\%80\#Text, Accessed 30 Dec 2020

5. Directive (EU) $2015 / 2193$ of the European Parliament and of the Council of 25 November 2015 on the limitation of emissions of certain pollutants into the air from medium combustion plants, https://eur-lex.europa.eu/legalcontent/EN/TXT/?uri=CELEX\%3A32015L2193, Accessed 30 Dec 2020

6. Tax Code of Ukraine, https://zakon.rada.gov.ua/laws/show/2755-17,

Accessed 30 Dec 2020

7. Commission notice. Guidelines on state aid for environmental protection and energy development for 2014-2020, https://zakon.rada.gov.ua/ laws/ show/984 009-14\#Text, Accessed 30 Dec 2020

8. O. Maliarenko, V. Horskyi, V. Stanytsina, O. Bogoslavska, $\cdot$ H. Kuts, An Improved Approach to Evaluation of the Efficiency of Energy Saving Measures Based on the Indicator of Products Total Energy Intensity, in Studies in Systems, Decision and Control, 298, ed. by V. Babak, V. Isaienko, A. Zaporozhets (Springer, Cham, 2020), 201216. (2020). doi:10.1007/978-3-030-48583-2_13

9. O. Bogoslavska, V. Stanytsina, V. Artemchuk, O. Garmata, V. Lavrinenko, Comparative Efficiency Assessment of Using Biofuels in Heat Supply Systems by Levelized Cost of Heat into Account Environmental Taxes, in Studies in Systems, Decision and Control (Springer, Cham, 2021 to be published)

10. D. Nong, M. Siriwardana, S. Perera, D.B. Nguyen, Growth of low emission-intensive energy production and energy impacts in vietnam under the new regulation, Journal of Cleaner Production, 225, 90103, (2019). doi:10.1016/j.jclepro.2019.03.299

11. M. Foumani, K. Smith-Miles, The impact of various carbon reduction policies on green flowshop scheduling. Applied Energy, 249, 3003156 (2019). doi:10.1016/j.apenergy.2019.04.155

12. R. Leisen, B. Steffen, C. Weber, Regulatory risk and the resilience of new sustainable business models in the energy sector. Journal of Cleaner Production (2019). doi:10.1016/j.jclepro.2019.01.330

13. V. Andreoni, Environmental taxes: Drivers behind the revenue collected. Journal of Cleaner Production, 221, 17-26. (2019). doi:10.1016/j.jclepro.2019.02.216

14. J. Zhang, Y. Zhang, Exploring the impacts of carbon tax on tourism-related energy consumption in China. 
Sustainable doi:10.1002/sd.1900

(2018).

15. S. Wang, L. J. Qing, H. Wang, H.Y. Li, Integrated assessment of environmental performance-based contracting for sulfur dioxide emission control in Chinese coal power plants. Journal of Cleaner Production, 177, 878-887. (2018). doi:10.1016/j.jclepro.2017.12.280

16. D. Nong, Development of the electricityenvironmental policy CGE model (GTAP-EPowerS): A case of the carbon tax in South Africa. Energy Policy, 140, 111375. (2020). doi:10.1016/j.enpol.2020.111375

17. P. K. Wesseh, B. Lin, Does improved environmental quality prevent a growing economy? Journal of Cleaner Production, 118996. (2019). doi:10.1016/j.jclepro.2019.118996

18. R. Kondo, Y. Kinoshita, T. Yamada, Green Procurement Decisions with Carbon Leakage by Global Suppliers and Order Quantities under Different Carbon Tax. Sustainability, 11(13), 3710. (2019). doi:10.3390/su11133710

19. D. Streimikiene, I. Siksnelyte, E. Zavadskas, F. Cavallaro, The Impact of Greening Tax Systems on Sustainable Energy Development in the Baltic States. Energies, 11(5), 1193. (2018). doi:10.3390/en11051193

20. U. Nissen, N. Harfst, Shortcomings of the traditional "levelized cost of energy" [LCOE] for the determination of grid parity. Energy, 171, 10091016. (2019). doi:10.1016/j.energy.2019.01.093

21. J.-L. Fan, S. Wei, et al., Comparison of the LCOE between coal-fired power plants with CCS and main low-carbon generation technologies: Evidence from China. Energy. (2019). doi:10.1016/j.energy.2019.04.003

22. J. Aldersey-Williams, I.D. Broadbent, P.A. Strachan, Better estimates of LCOE from audited accounts - A new methodology with examples from United Kingdom offshore wind and CCGT. Energy Policy, 128, 25-35. (2019). doi:10.1016/j.enpol.2018.12.044

23. G. Zang, J. Jia, S. Tejasvi, A. Ratner, E. Silva Lora, Techno-economic comparative analysis of Biomass Integrated Gasification Combined Cycles with and without $\mathrm{CO}_{2}$ capture. International Journal of Greenhouse Gas Control, 78, 73-84. (2018). doi:10.1016/j.ijggc.2018.07.023

24. Alfa-Invest,

https://ainvest.com.ua/aktualno/tablitsa-teplotvornosti.html, Accessed 30 Dec 2020

25. 1.A.4 Small combustion, https://www.eea.europa.eu/ru/publications/rukovods tvo-emep-eaos-po-inventarizaciivybrosov2016/chast-b-glavy-posvyaschennye-tehnicheskimaspektam/1-energetika/1-a-szhiganie/1-a-4-maloeszhiganie/view, Accessed 30 Dec 2020

26. Tables for guidelines, https://www.altstu.ru/media/f/Prilozhenie-2- tablicy.pdf, Accessed 30 Dec 2020

27. O.G. Levitska, Comparative analysis of emissions of harmful substances in the use of alternative natural gas to biofuels, http://nbuv.gov.ua/UJRN/Vldubzh $201920 \quad 15$, Accessed 30 Dec 2020

28. Calculation of emissions into the atmosphere during natural gas combustion, http://www.te.ukrstat.gov.ua/files/respondent/2tp.pd f, Accessed 30 Dec 2020

29. GKD 34.02.305-2002 "Emissions of pollutants substances into the atmosphere from power plants", http://lib.sumdu.edu.ua/library/docs/rio/2005/m976. doc, Accessed 30 Dec 2020

30. Carbon Taxes in Europe in 2019, https://taxfoundation.org/carbon-taxes-in-europe2019/, Accessed 30 Dec 2020

31. V. Stanytsina, G. Kuts, O. Teslenko, O. Malyarenko, Comparative analysis of the average cost of heat energy produced in boilers of different power, taking into account the environmental component. Energy Technologies \& Resource Saving, 2, 55-62. (2020) doi:10.33070/etars.2.2020.07 